Liイオン二次電池用炭素系負極材料開発へのコンピュータ利用

\author{
川崎晋司*
}

(平成15年1月20日受理, 平成15年2月28日採択)

\title{
Personal Computer Aided Development of Carbon Anode Materials for Li Ion Secondary Battery
}

\author{
Shinji Kawasaki*
}

\begin{abstract}
This paper elaborates on an electrochemical measurement system using personal computer for development of carbon anode materials for Li ion secondary battery. Some analysis methods for the obtained data by the system are explained. Theoretical investigations on the electrochemical properties of carbon nanotubes are also reviewed.
\end{abstract}

KEYWORDS : Personal computer, Li ion battery, Carbon nanotube

\section{1. はじめに}

リチウムイオン二次電池は, いまや小型の情報通信機器に 欠かせないデバイスとなった1),2)。その成功の要因の1つに, 負極材料として炭素材料を採用したことが挙げられる。現在, 黒鉛などが主に負極材として利用されているが, 高容量化な どリチウムイオン二次電池の改良のために新たな負極材料の 開発にしのぎが削られている。なかでも, カーボンナノチュ ーブは高い比表面積, 空隙の多い構造から効率よく Liイオン を出し入れできる貯蔵庫としての性能が期待され, 多くの研 究者により研究されている3》。私たちの研究室でも, カーボン ナノチューブをはじめとする新炭素材料の電池電極特性の評 価を行ってきている4)-6)。

さて, 電気化学測定実験は通常 (a) 測定セルの構築, (b) 電 気化学測定, (c) 測定データの処理および解析, といった手順 で進められる。このうち主に(b), (c) の段階でコンピュータ が利用される。また, 解析時にはデー夕の解析だけでなく適 当なモデルを用いての理論計算が有効である。本稿では実際 に私たちの研究室で使用している電気化学システム, および カーボンナノチューブを電極に用いて測定したデータをもと に,どのようにコンピュータが利用されているかについて説 明する。また, カーボンナノチューブの電気化学特性に関す る理論的研究のいくつかを紹介する。

\section{2. 電気化学測定へのコンピュータの利用}

ここでは電気化学測定としてサイクリックボルタンメトリー $(\mathrm{CV})$, および充放電測定 (クロノポテンショメトリー $(\mathrm{CP})$ ) を取り上げる。CV法は作用電極の電位を一定速度で走査し, 一定範囲で往復させる測定方法でリニアスイープボルタンメ トリーの一種である。一方, CP法は作用電極と対極の間に一 定電流を流したときの作用電極電位の時間変化を測定する。 充放電測定が主に一定電圧範囲内での容量を測定するという 実用性を調べることに重点をおくのに対し，CV法は被測定系 で起こる電気化学反応を比較的短時間に簡便にとらえること ができるという特徴をもっている。さて, CV 測定にあたって は（1）電位走査のためのファンクションジェネレータ，(2) 電位プロファイルを作用電極に加え, 対極との間に流れる電 流をとらえるためのポテンショスタット, (3) 電位一電流デ ータを記録するレコーダの3つあるいは同等の機能を有する 装置が必要である (Fig.1 (a))。最近はこれらの機能を一体化 した専用の装置があるが一般に数百万円と高価である。充放 電測定装置も専用のものが市販されているがやはり高価であ る。これらの装置では測定データをデジタルデータとして保 存でき, 後の解析を行う上でプロッターによる印字に比べ格 段に有利である。しかしながら，これらの専用の装置をいく つも購入することは, これから電気化学測定を始めようとい う方や,すでにFig.1 (a) のような装置を有している方には大 きすぎる投資かもしれない。ところが, CV測定, 充放電測定

* Corresponding Author, E-mail: skawasa@giptc.shinshu-u.ac.jp 信州大学繊維学部素材開発化学科：干386-8567 上田市常田3-15-1

Faculty of Textile Science and Technology, Shinshu University : 3-15-1 Tokida, Ueda 386-8567, Japan 
の両方の測定にパーソナルコンピュータ $(\mathrm{PC})$ をうまく活用 することでFig.1 (b)のように(1) ポテンショ/ガルバノス夕 ット，(2) AD/DA（アナログーデジタル/デジタルーアナロ グ) コンバー夕，(3) PC，の組み合わせで対応でき，デジタル データの保存が可能になる。PCは数世代前の中古品で十分 であり AD/DAコンバータと合わせても10万円以下で入手可 能である。ポテンショ/ガルバノスタットも安価なものは10 万円程度であるので, 少しプログラムの手間はかかるものの 小さな投資で実用的な電気化学測定システムを構築すること ができる。

(a)

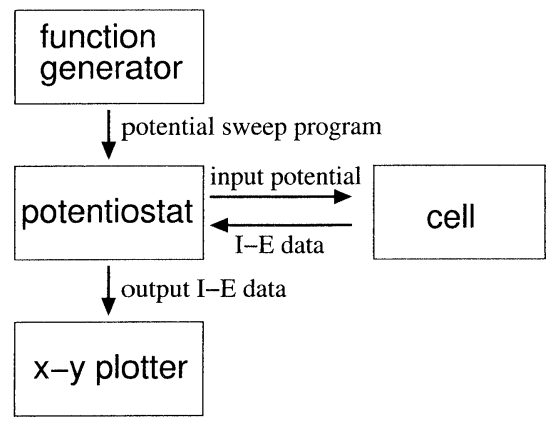

(b)

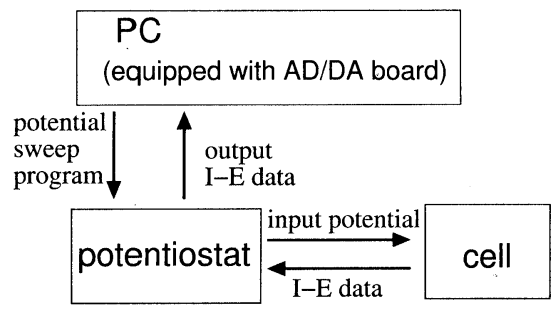

Fig.1 Electrochemical measurement systems, (a) assembled with analogue machines, (b) using personal computer.

(a)

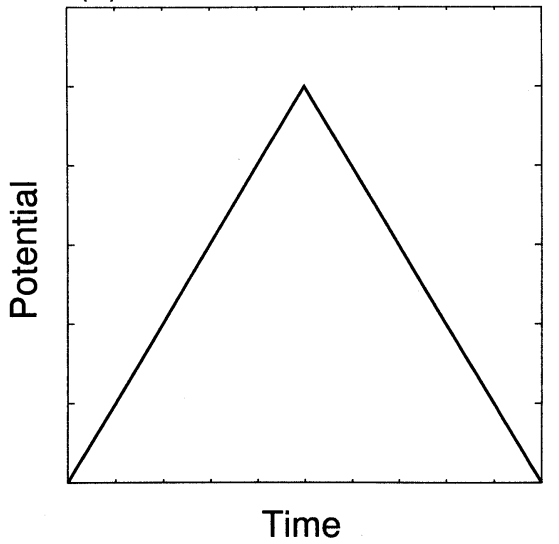

Fig.1 (a) とFig.1 (b) を見比べてもらえばわかるように, パ ソコンはファンクションジェネレータとレコーダの両方の役 割を果たしている。CV測定の場合はパソコンで設定した電 位プロファイルをDAコンバータを介してポテンショスタッ トへ伝える。Fig.2 (b) に示すように電位プロファイルは厳密 にはリニアスイープにならず,ステップ状になる。しかしな がら，16bit DAコンバー夕を使用し，-5Vから5Vまでを制御 可能範囲に設定したとすると, 操作可能な電位間隔は $10 \mathrm{~V} / 2^{16} \simeq 0.15 \mathrm{mV}$ と小さい。実験系に応じて制御範囲を絞り 込んだり,DAコンバータの変換ビット数を増やせば,よりリ ニアスイープに近づけることが可能である。実際, 私たちの 研究室で扱っている系ではFig.1 (a)，(b) の両方で測定した CV図には違いは見られない。Fig.1 (b) のシステムでは電位, 電流データはADコンバー夕を介してPCに取り込ませる。電 流值はポテンショスタット側で電圧值に変換されるのが一般 的であり,この出力を取り込むのは容易である。微小電流し か流れないような系ではリニアアンプを用いて電圧值を大き くすることもできるが16bit ADコンバータを用いればアンプ がなくても十分精度よく測定できる場合が多いと考えられ る。充放電測定の場合にはポテンショ/ガルバノスタットを ガルバノモードにして利用する。ガルバノスタットでは外部 からの印加電圧によりセルに流す電流を制御できるような端 子を備えているのが一般的であり,ここにDAコンバータを介 してパソコンから信号を送ることによりセルに定電流を流す ことが可能になる。定電流電解を開始したら一定時間間隔で セル電位を読み取ればCP曲線を得ることができる。あらか じめ設定していたカットオフ電位に達したら, 逆向きに電流 を流すことにより充放電を切り換えることが可能である。こ こでは CV, CP測定のみを取り上げたが, 容易に想像できるよ うに印加する電位パターンは簡単に変更できるので, 種々の パルスボルタンメトリーなどへの応用もFig.1 (b) の組み合わ せで対応可能である。

(b)

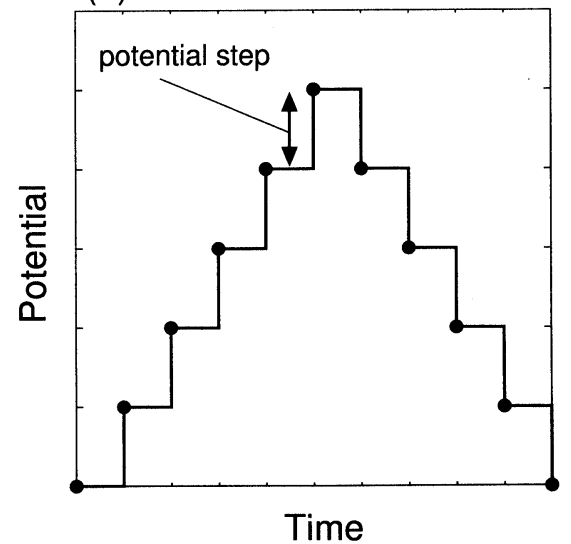

Fig.2 (a) analogue potential sweep, (b) digital potential sweep. 


\section{3. 測定データ処理, 解析のためのコンピュータの利用}

\section{1 微分クロノポテンショグラムの算出}

クロノポテンショグラム (CP曲線) からは一定電位範囲で の容量が求まるだけでなく, リチウムイオンの挿入・脱離が 起こる電位など多くの情報が読み取れる。しかし，ノイズが 大きかったりプラトーが明瞭でない場合には, そうした電位 の決定が困難である場合が多い。こうした場合でもデー夕を 平滑化し, CP曲線の微分值 (微分クロノポテンショグラム) を とると解析が容易になることがある。私たちの研究室では, 平滑化を二次多項式適合を用いた移動平均法により行ってい る $($ Fig.3)。この方法は, まずデータから微小区間を取り出し, その区間を二次式にあてはめ平滑化点を求め, 次いで微小区 間を順次移動させることで全体を平滑化するものである。単 純平均に比べデータの変動が大きい場合にも平滑化による歪

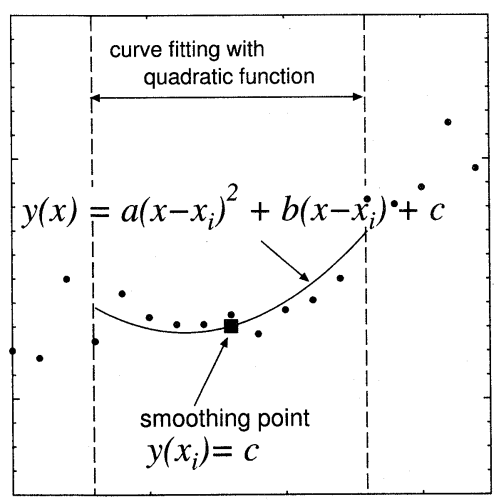

Fig.3 Moving averaging method using curve fitting with quadratic function.

(a)

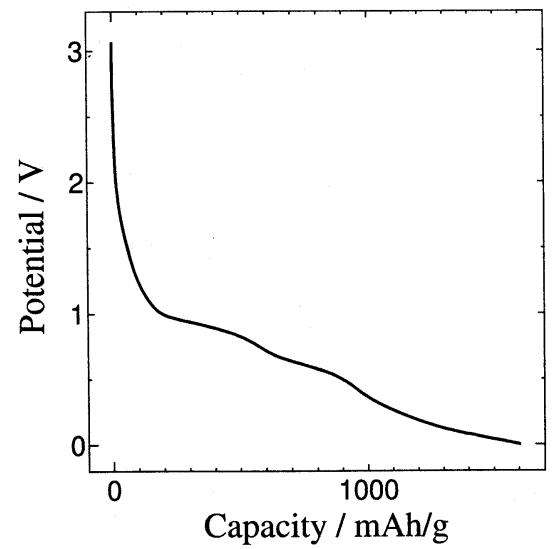

みを小さくできるメリットがある。また, Fig.3に示すあては め関数 (二次関数) の導関数は

$$
y^{\prime}(x)=2 a\left(x-x_{i}\right)+b
$$

となり, 点 $x_{i}$ の微分值 $y^{\prime}\left(x_{i}\right)=b$ は平滑化と同時に求まる。こ こで, $a, b$ Fig.3に示したあてはめ関数のそれぞれ二次,一次 の係数である。

Fig.4 (a) はレーザーアブレーション法で作成した単層カー ボンナノチューブ (SWNT) を作用極, $\mathrm{Li}$ 金属を対極とする試 験セルを用いて測定された第一放電 (Liイオンの挿入) 曲線 である。グラファイトの理論容量 $372 \mathrm{mAh} / \mathrm{g}$ をるかに超え $2000 \mathrm{mAh} / \mathrm{g}$ 近くまで放電曲線は伸び, 放電容量はきわめて大 きい。残念ながら充電容量はそれほど大きくはならず実用化 に向けては大きな不可逆容量が問題となる。この問題を解決 するためには, どのようなメカニズムで充放電が起こってい るのかを理解する必要がある。前述の方法でFig.4 (a) から微 分 CP曲線を求めたものがFig.4 (b) である。この微分CP曲線 からFig.4 (a) の放電曲線が (この場合は図からも明らかだが) 大きく分けて3段階のプロセスからなることがわかる。Fig.4 (b) の1, 0.6,0.05V付近のピークはそれぞれ表面酸素化学種の 還元, SEI (Solid Electrolyte Interphase) の形成, SWNTへのLi イオンの挿入に対応すると考えられる。

\subsection{CV図の解析}

$\mathrm{CV}$ 法は比較的簡単に測定を行うことができるにもかかわ らず, 得られるCV図には多くの情報が含まれている。例えば 酸化還元に伴うCV曲線のピーク位置, 高さなどから半波電位 や反応の可逆性についての情報を知ることができる。もう少 し, 細かな情報については測定や解析に工夫が必要である。 以下に比較的簡単な解析法について紹介する。

(b)

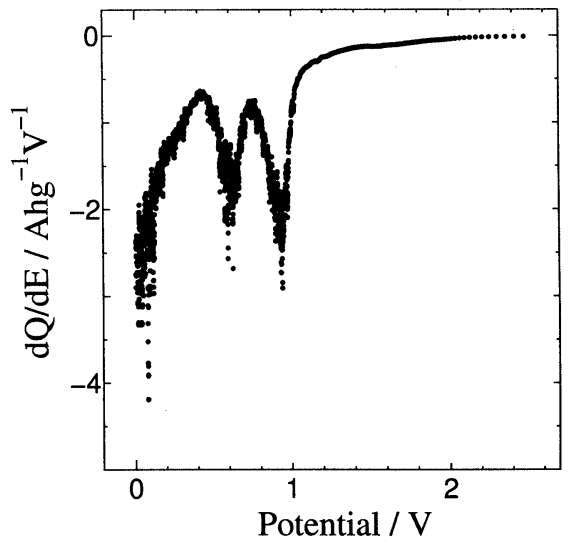

Fig.4 (a) 1st discharge profile measured with a Li/EC+DEC/SWNT electrochemical cell. (b) Differential CP diagram derived from (a). 


\section{3 酸化還元電気量の算出}

Fig.2 (b) に示すようにコンピュータを利用したCV測定で は一定時間間隔でステップ電位をかけている。しかしながら， 実際に取り込まれる作用極の電位はさまざまな要因により必 ずしも一定間隔にはなっていない。そこで,まず区分ラグラ ンジュ補間法などを用いて電流值の内挿デー夕 $\left(y_{1}, y_{2}, \cdots\right)$ を一定電位ステップ間隔 $(\Delta x)$ で求めておく。 $\Delta x$ を十分小さ くとっておくと次式のような簡単な計算で近似的に電気量を 算出することができる。

$$
\sum y_{i} \Delta x \times \frac{1}{v}
$$

ただし,vは電位走查速度である。このようにして求めた電気 量は酸化還元反応の反応電子数の決定などに利用できる。

Fig.5はアーク放電法により合成したホウ素をドープした 多層カーボンナノチューブ (MWNT) を作用極, Li金属を対極 とする試験セルを用いて測定されたCV図である。Fig.5に示 すように還元側には $1.3 \mathrm{~V}$ 付近に表面酸素化学種の還元による ピーク，0.7V付近にはSEI形成によるピーク，0.05V付近には Liイオンの挿入によるピークが観測される。ホウ素ドープさ れたMWNTは,これまで報告されているMWNTやSWNTと は異なり, Liイオンの挿入・脱離過程に良好な可逆性が認め られ良い電極特性を示すが, Fig.5に示すSEI形成に消費され る電気量は無駄なエネルギーとなるのでこれを小さくする必 要がある。

\section{$3.4 \mathrm{CV}$ 図のシミュレーション}

$\mathrm{CV}$ 曲線の形状は反応物 (酸化体, 還元体) の酸化還元電位, 電極へ(あるいは電極から) の拡散速度, 電極との電子授受の 速度, 先行 ·後行反応の有無, 反応電子数などの非常に多くの パラメータが複雑に関わり決定される。したがって, CV図に 含まれている情報をすべて解析的に求めるのは困難であると 考えられる。そこで, 個々の被測定系に対しCV図を支配する 主要なパラメータだけを抜き出してモデル化し，これらのパ ラメータを最適化することで実測值の再現を試みるシミュレ ーションが行われる。シミュレーションの詳細は成書7,8 に ゆずるが, 基本的には拡散方程式をいかに解くかがかぎとな る。私たちのところではBard ( $^{8}$ の手法にならい差分法によ りこれに対応している。パラメータの調整は試行錯誤的にな らざるを得ないが, 測定したCV曲線を特徴づける支配的なパ ラメータを見出したりするには有用な方法と思われる。また, 電極電位を変えたときの電極からの距離と酸化体・還元体の 濃度の関係が可視化できるので, 電気化学の初学者にはとて も教育的である。

Fig.6は酸化還元電位を $-1.0,-1.2 \mathrm{~V}$ に設定し, 反応電子数 をそれぞれ2,1とした2段階の反応についてシミュレーショ ンしたCV図である。この場合, 酸化体, 還元体の拡散速度を 同じにするなど条件を単純化しているが, 実際の系では複雑

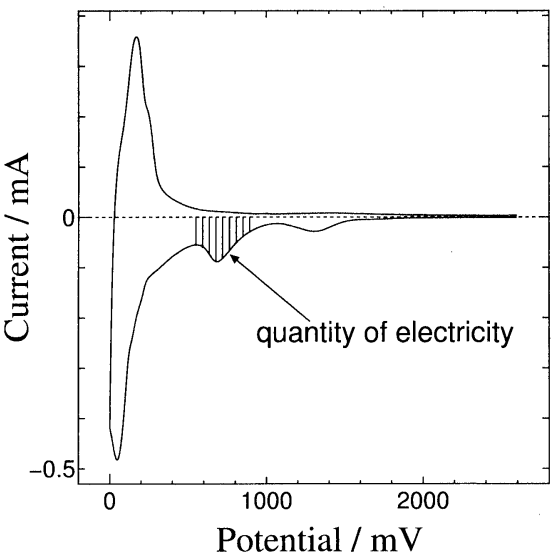

Fig.5 Cyclic voltammogram measured with a $\mathrm{Li} / \mathrm{EC}+\mathrm{DEC} /$ MWNT (B-doped) electrochemical cell at a potential sweep rate $v=0.1 \mathrm{mV} / \mathrm{s}$.

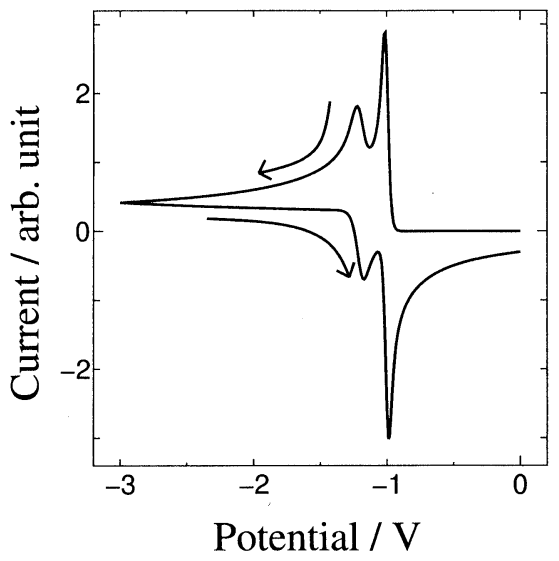

Fig.6 Simulated cyclic voltammogram.

な条件設定が必要な場合が多い。

\section{4. 電気化学特性に関わる理論計算}

炭素材料に限らないが電気化学特性の評価が実験的研究 だけでは十分でない場合に, 理論計算から得られる情報が役 立つことが多い。とりわけ非晶質材料については電気化学反 応に伴う構造変化を実験的にとらえることが容易ではなく， 反応メカニズムの理解が困難である場合が多く, 理論的アプ ローチは重要である。ここでは一例としてカーボンナノチュ ーブの電気化学特性評価に関わる理論研究のいくつかを紹介 する。

カーボンナノチューブは発見以来その高い比表面積, 空隙 の多い構造から効率よくリチウムイオンを出し入れできる貯 蔵庫としての性能が期待され, 多くの研究者により研究され ている。カーボンナノチューブは合成法によりさまざまな形 状, 形態をもつので充放電容量, サイクル効率など電極特性に 
ついて報告されている数值には大きな幅がある。また，充放 電メカニズムが理解されているものは少なく, どのような反 応経路でどういうサイトにリチウムイオンが吸蔵されるかに 大変興味がもたれている。実験的にもさまざまな分光手段な どを通してメカニズムの解明への取り組みがなされているが 十分理解されているとは言い難い。特に興味がもたれるのは 果たして単層カーボンナノチューブのチューブ内にリチウム を吸蔵できるかどうかである。これに関連してKarら9)と Meunierら ${ }^{10)}$ は第一原理計算により6員環中央からリチウム イオンがチューブ内部へ入る際のエネルギー障壁を計算した ところ,いずれも大きな值となり6員環からの侵入,つまりチ ユーブ側面からチューブ内部一の拡散は困難であることを示 した。一方, 彼らの計算によれば開口部もしくは傾面であっ ても9員環程度の大きさがあればその中央からリチウムイオ ンはほとんどエネルギーバリアを感じることなく挿入可能で ある。また, Meunierらはいったんリチウムがチューブ内部に 入ってしまえば, 内部ではほぼ自由に拡散できるという計算 結果を得ている。このような計算結果は, 物理・化学的処理 により,チューブ端を開口し側面へ欠陥を導入すると充放電 容量が増大寸るという実駼結果と調和的である。このことは 理論計算が電極材の設計に有効であることを示していると理 解できる。一方, Zhao ${ }^{11}$ らは第一原理計算により単層カーボ ンナノチューブ内部にリチウムがドープされるとチューブ断 面が円形から大きくひずむことを示している。このようなチ ユーブ1本の構造変化について実験的研究はないが, 理論計算 で示されているように構造が大きく変化するのであれば充放 電メカニズムとも関連すると考元られ, 何らかの手法により 実験的にも研究することが重要だと思われる。

これらのように, 炭素材料の電気化学特性評価においても理 論計算は今後ますます重要になってくることが期待される。

\section{謝 辞}

本稿で取り上げた測定データは信州大学繊維学部東原研究 室 (東原秀和教授, 沖野不二雄助教授, 川崎晋司助手) で測定 したものである。データの測定ならびに本稿を書くにあたつ て議論いただいた信州大学大学院博士前期課程星野典子氏に 厚く感謝します。

\section{文 献}

1）芳尾真幸, 小沢昭弥, リチウムイオン二次電池 (第二版) (2000) 日刊工業新聞社.

2）小久見善八，池田宏之助，はじめての二次電池技術 (2001) 工業調査会.

3）川崎晋司, 東原秀和, カーボンナノチューブの合成・評価, 実用化とナノ分散・配合制御技術 (2003) pp.254-264, 技 術情報協会.

4) N. Liu, H. Touhara, F. Okino and S. Kawasaki, J. Electrochem. Soc. 143 (1996) 2267-2272.

5) H. Touhara, J. Inahara, T. Mizuno, Y. Yokoyama, S. Okano, K. Yanagiuchi, I. Mukopadhyay, S. Kawasaki, F. Okino, H. Shirai, W. H. Xu, T. Kyotani and A. Tomita, J. Fluorine Chem. 114 (2002) 181-188.

6) I. Mukhopadhyay, N. Hoshino, S. Kawasaki, F. Okino, W. K. Hsu and H. Touhara, J. Electrochem. Soc. 149 (2002) A39-A44.

7) D. K. Gosser, Cyclic voltammetry : simulation and analysis of reaction mechanisms (1993) Wiley-VCH Verlag.

8) A. J. Bard and L. R. Faulkner, Electrochemical Methods (1980) John Wiley \& Sons.

9) T. Kar, J. Pattanayak and S. Scheiner, J. Phys. Chem. A 105 (2001) 10397-10403.

10) V. Meunier, J. Kephart, C. Roland and J. Bernholc, Phys. Rev. Lett. 88 (2002) 075506-1-4.

11) J. Zhao, A. Buldum, J. Han and P. Lu, Phys. Rev. Lett. 85 (2000) 1706-1709. 